\begin{tabular}{c} 
OSOBA I MIŁOŚĆ \\
Filozofia ChrześcijańSKa $\bullet$ Tom 11, Poznań 2014 \\
Uniwersytet IM. Adama Mickiewicza w Poznaniu $\bullet$ Wydziat Teologiczny \\
\hline
\end{tabular}

\title{
ANDRZEJ JASTRZEBBSKI
}

Katolicki Uniwersytet Lubelski

\section{Bóg w personalizmie Bordena Parkera Bowne'a}

\author{
God in the Personalism of Borden Parker Bowne
}

Prezentowany tekst przedstawia koncepcję Boga w personalizmie Bordena Parkera Bowne'a. Filozofia ta stanowi niewątpliwie mniej znany wycinek historii myśli ludzkiej, niemniej jednak jest warta przedstawienia polskiemu czytelnikowi. Biorąc pod uwagę niewielką znajomość tego myśliciela w Polsce, przed przystąpieniem do zreferowania koncepcji Boga w ujęciu Bowne'a, przybliżymy najpierw w ogólnych zarysach całość jego filozofii, którą sam określa mianem personalizmu. Zabieg ten wydaje się konieczny dla właściwego zrozumienia teizmu filozofa amerykańskiego.

W personalizmie Bowne'a Bóg jest zwornikiem całej filozofii. Po pierwsze dlatego, że Bowne sam był praktykującym chrześcijaninem i uprawianie filozofii w swych założeniach ateistycznej było w jego przypadku nie do pomyślenia; po drugie dlatego, że Osoba Boga stała się dla filozofa amerykańskiego wzorem rozumienia osoby w ogóle, natomiast istnienie osobowego Boga podstawowym aksjomatem jego personalizmu. Dzieło Bowne'a pt. Theism to klasyczny przykład ewolucji myśli dotyczącej tego zagadnienia w Stanach Zjednoczonych u schyłku XIX wieku.

Personalizm Bowne'a jest przykładem tego, jak z przekonaniem można racjonalnie bronić stanowiska teistycznego przeciwko ateizmowi w okresie, gdy modernizm chciał umniejszyć racjonalne oparcie dla wiary chrześcijańskiej, szukając go raczej na pozycjach fideistycznych ${ }^{1}$.

Bóg jest określany przez Bowne'a w wielu terminach i stanowi to niewątpliwie o oryginalności tego autora. Określenia te pozwalają na uzyskanie pewnych odcieni znaczeniowych, dających lepszy wgląd w bogactwo jego ujęć. U filozo-

\footnotetext{
${ }^{1}$ Por.: L. Farré, Personalistic Idealism of Bowne, "The Personalist" XXX (1949), s. 53.
} 
fa amerykańskiego znajdujemy następujące terminy określające Boga: Absolut, Nieskończoność, Nieskończony, Najwyższy Umysł, Kosmiczny Umysł, Kosmiczna Osoba, Najwyższa Osoba, Działający, Stwórca, Duch, Najwyższa Wola, Żyjąca Wola, Żyjąca Osoba, Osobowa Podstawa Świata.

Jak wspominano wyżej, przedstawianie teizmu Bowne'a poprzedzimy ogólną charakterystyką filozofii tego autora $\mathrm{z}$ uwzględnieniem jej kontekstu historycznego oraz przyjmowanych założeń natury ogólnej. Następnie zreferujemy jego argumentację za istnieniem Boga oraz Jego specyficzną rolę w wykładni rozumienia natury. Główną część wywodu stanowić będzie charakterystyka Boga jako Osoby w ujęciu Bowne'a. Analizy nasze zakończymy podsumowaniem znaczenia koncepcji filozofa amerykańskiego w rozwoju personalizmu.

\section{CHARAKTER FILOZOFII BOWNE'A}

Aby lepiej zrozumieć charakterystykę Boga w personalizmie Bowne'a, podamy najpierw kilka informacji wprowadzających w życie i twórczość tego filozofa $^{2}$. Bowne urodził się 14 stycznia 1847 roku w Leonardville (USA), a zmarł 1 kwietnia 1910 roku w Bostonie. Jego ważniejsze publikacje to: Studies in Theism (1879), Metaphysics (1882), Principles of Ethics (1892), Theory of Thought and Knowledge (1897) oraz Personalism (1908) ${ }^{3}$.

Jedną z naczelnych tez filozofii Bowne'a, którą określił „personalizmem”, było twierdzenie, że aby uzyskać adekwatne rozumienie rzeczywistości, musimy odkryć moc, która za ową rzeczywistością stoi, oraz odpowiedzieć na pytanie, dlaczego działa właśnie $\mathrm{w}$ ten, a nie w inny sposób? Personalizm miał być dla Bowne'a antidotum na naturalizm rozumiany jako filozoficzna doktryna oraz na materializm rozumiany jako metoda naukowa, które stawały się modne w jego czasach (koniec XIX w.). Bowne nie odrzucał nauk przyrodniczych jako takich ani nie negował ich roli w poznawaniu rzeczywistości. Nie dostrzegał też sprzeczności między naukami szczegółowymi a filozofią, ponieważ obie dziedziny badań miały się w jego przekonaniu wzajemnie uzupełniać.

Personalizm Bowne'a ma korzenie w Augustyńsko-Kartezjańskiej afirmacji roli jaźni; Leibnizjańskim skoncentrowaniu się na duchowej jednostkowości oraz aktywności podmiotu; immaterializmie George'a Berkeleya (natura to język Boga); akcentowaniu przez Immanuela Kanta aktywności intelektu w procesie poznawczym oraz wątkach personalistycznych w myśli Rudolfa H. Lotzego niemieckiego nauczyciela Bowne'a, twierdzącego, że jaźń lub osoba jest osta-

${ }^{2}$ A. Jastrzębski, Zarys personalistycznej metafizyki Bordena Parkera Bowne’a, ,Roczniki Filozoficzne KUL" 1(2008), s. 397-415.

${ }^{3}$ Polskie tłumaczenie J. Kłosa oraz B. Gacki: B.P. Bowne, Personalizm, Lublin 1994. 
teczną kategorią empiryczna, tłumaczącą zarówno samo doświadczenie, jak i całą naturę. Ważną rzeczą dla zrozumienia filozofii Bowne'a jest też dostrzeżenie jej kontekstu. Stanowią go doświadczenia żywej jednostki ludzkiej: jej pragnienia, przekonania i charakter, a ostatecznie sama świadomość żyjącego podmiotu ${ }^{4}$.

Jedna z naczelnych tez metafizyki personalistycznej Bowne’a głosi, że kiedy obserwujemy świat, dostrzegamy, iż jest on niesamowystarczalny i musi być odniesiony do zewnętrznej przyczyny. Przyczyną tą jest dla Bowne'a osobowy Bóg, stwarzający wspólny wszystkim ludziom (osobom skończonym) świat doświadczenia. Dzięki swej powszechności świat ten jawi się ludziom jako obiektywny.

Personalizm Bowne'a jest formą idealizmu, utrzymująca, że duchowa osoba, a nie bezosobowa materia, jest ostatecznym wytłumaczeniem rzeczywistości. Rzeczywistość ta jest natury duchowej, inteligibilnej. Powyższe zdanie prowadzi Bowne'a do systemu wniosków budujących całościową wizję metafizyki opartą na jednej zasadzie - samowystarczalności osoby ${ }^{5}$.

Jako punkt wyjścia jego filozofii można wskazać następujące założenia-aksjomaty:

- Istnieje nie tylko podmiot myślący, ale też coś więcej - przynajmniej inne osoby.

- Świat stanowi wspólne doświadczenie dla poznających go osób.

- Nie wydaje się, żeby świat był tylko iluzją, subiektywnym podobieństwem wrażeń.

- Świat jest niezależny od skończonej myśli i świadomości.

- Świat przyrody wraz ze sposobem, w jaki się ukazuje: czasem i przestrzenia, istnieje ostatecznie jako działanie Boga ${ }^{6}$.

Z punktu widzenia Bowne'a idealizm oznacza, że istnienie materialnego świata wynika z realizowania się idei. Zrealizowana idea to taka, w której odnajdujemy wewnętrzną przyczynowość. Bowne nie przyjmował idealizmu rozumianego jako zespół czystych idei, poza którymi nic nie ma. W tym sensie idealizm nie był terminem najszczęśliwszym dla określenia jego filozofii. Rzecz różni się

\footnotetext{
${ }^{4}$ H.W. Schneider, Bowne's Radical Empiricism, w: Representative Essays of Borden Parker Bowne, ed. W.E. Steinkraus, New York 1981, s. XII.

5 "The most distinctive form of personalism is not reached until personalism becomes a philosophical method as well as a body of conclusions. It is this that Bowne has given us, a systematic methodological personalism, in which the whole of metaphysics is organized around one central and all-illuminating principle - that of the self-sufficiency of personality" - A.C. Knudson, The Philosophy of Personalism, New York-Cincinnati-Chicago 1927, s. 87.

${ }^{6}$ B.P. Bowne, Theism, New York 1902, s. 328-329; por.: B.P. Bowne, Philosophical Idealism, w: Representative Essays of Borden Parker Bowne, ed. W.E. Steinkraus, New York 1981, s. 9.
} 
od czystej idei w ten sposób, że jest ona ideą powołaną do istnienia przez jakąś moc. Istnienie Woli i Mocy (Boga) u podstaw świata staje się naczelnym postulatem personalizmu Bowne'a.

Jedyną metafizycznie realną rzeczywistością są dla filozofa amerykańskiego osoby, czyli jaźnie 7 . Ich realność nie zasadza się na trwałej substancjalności, będącej w klasycznym ujęciu podstawą do zmiennych cech przypadłościowych (suppositum), ale na świadomym doświadczeniu osoby. Bowne nazywa swą doktrynę jaźni empiryzmem, ponieważ jaźń ujawnia się zawsze w jakieś formie doświadczenia. Dodaje do tego termin „transcendentalny” dlatego, że jaźń wymyka się wszelkim kategoriom, choć sama nadaje im sens. Kategorie takie jak: byt, przyczyna, działanie, czas i przestrzeń, zależą w swym rozumieniu od doświadczenia osoby. Osoba jest faktem podstawowym, który wyjaśnia wszystkie kategorie, ale żadna $\mathrm{z}$ tych kategorii nie jest w stanie wyjaśnić jej samej ${ }^{8}$.

Tak zarysowane fundamenty personalizmu Bowne'a przypominają coś w rodzaju systemu aksjomatycznego. Podstawowym aksjomatem w tym systemie jest osoba, a dokładniej osobowy Bóg, dzięki któremu można uzasadnić istnienie całej rzeczywistości. Opierając się na tym aksjomacie, Bowne buduje dalej swoją filozofię i trzeba przyznać, że czyni to dość konsekwentnie. Filozof obiera drogę kartezjańskiego wątpienia, lecz jakby na skróty, tj. przyjmuje implicite argumentację Kartezjusza, ale sam się do niej wprost nie odwołuje. Dochodzi za to do wniosku, a raczej postulatu, że świat materialny nie ma sam w sobie racji istnienia, a odnajduje ją dopiero w Najwyższym Bycie Osobowym9.

\section{ARGUMENTY ZA ISTNIENIEM BOGA}

Bowne był przekonany, iż możliwość poznawania świata daje możliwość najmocniejszego uzasadnienia dla teizmu, nie twierdząc jednak, że świat ten jest poznawalny całkowicie przez skończony umysł. Nie uważał przy tym, że jakikolwiek dowód na istnienie Boga może być ostateczny i definitywny.

Bowne widział w świecie większą ilość znaków uporządkowania i celowości niż w ludzkim działaniu i stąd było dla niego rzeczą rozsądną przyjęcie istnienia Kosmicznego Umysłu jako ukrytego za naturalnymi procesami ${ }^{10}$. Co więcej, świat jawi się nam jako system powiązanych idei, których skończony umysł nie jest

\footnotetext{
${ }^{7}$ Słowo ,jaźń” wprowadził do polskiego języka filozoficznego B. Trentowski. Rozumiemy je jako podmiot samo/poznający, podmiot aktów psychicznych, w klasycznej antropologii „dusza”. Bowne używał w tym kontekście słowa „self”.

${ }^{8}$ B.P. Bowne, Metaphysics: A Study in First Principles, New York 1898, s. 99-100.

${ }^{9}$ Por. A. Jastrzębski, Problem mind-body w ujęciu Szkoły Bostońskiej na przykładzie Bordena Parkera Bowne'a, „Kwartalnik Filozoficzny” 2(2010), s. 83-105.

${ }^{10}$ P.A. Bertocci, Borden Parker Bowne and His Personalistic Theistic Idealism, w: The Bo-
} 
w stanie w całości odczytać. Za takim systemem musi więc stać Umysł Nieskończony. Bóg jest ostateczną podstawą systemu idei, a także poznawalności prawdy ${ }^{11}$.

Filozof amerykański nazwał ten argument ,pozytywnym dowodem na projekt", ukazującym, że wiele procesów w naturze jest zdeterminowanych ze względu na jakiś cel ${ }^{12}$. Struktura całego kosmosu jest celowa ${ }^{13}$. To obiektywna rzeczywistość - a z drugiej strony system praw, który je opisuje. Oba porządki są sobie podporządkowane ${ }^{14}$.

Gdy postrzegamy świat jako inteligibilny, dochodzimy do Najwyższego Intelektu nie tylko jako źródła świata, ale też jako tego, bez czego nie byłby nawet możliwy, lecz stałby się absurdalny i niezrozumiały. Świat znaczeń zakłada intelekt. System relacji suponuje intelekt jako swe źródło oraz siedlisko. Gdy postrzegamy świat w jego uprzyczynowaniu, zostajemy odniesieni do działającego Intelektu, przez który istnieje i z którego na zawsze wychodzi. Świat posiada swą formę i znaczenie w myśli Bożej, a swą realność w Bożej woli [tłum. A. J.] ${ }^{15}$.

Argument ten jest do pewnego stopnia powtórzeniem rozumowania Berkeleya, który poznawalność Boga wyprowadzał z poznawalności natury. Bowne mówi wszakże też o inteligibilności natury. Sama poznawalność świata sugeruje obecność Intelektu, który się nam na takiej drodze ujawnia. Intelekt musi się spotkać z intelektem. Nie moglibyśmy czytać języka natury, jeśli ktoś wpierw nie powiedziałby czegoś poprzez naturę. Prawa natury są stałe i można na nich polegać. Świadczy to także w pewien sposób o wiarygodności i wierności Boga ${ }^{16}$.

Zdaniem Bowne'a, rozumienie Boga jako Platońskiego Demiurga dla uzasadnienia teizmu nie jest wystarczające. Tak można by odczytać argument z inteligibilności świata w wersji słabej. Jeśli nie przyjmiemy, że Projektant świata jest nieustannie zaangażowany w jego tworzenie - lub dokładniej - stwarzanie, nie dochodzimy do ujęcia w pełni teistycznego ${ }^{17}$. „Z teistycznego punktu widzenia sam wszechświat nie istnieje w sposób statyczny. Takie istnienie może jedynie posiadać Boska myśl, która realizuje się poprzez Bożą wolę, i właśnie ta myśl powinna znaleźć wyraz w porządku naszego doświadczenia"18.

ston Personalist Tradition in Philosophy, Social Ethics, and Theology, ed. P. Deats, C. Robb, Macon [Georgia] 1986, s. 72.

${ }^{11}$ E. Gilson, T. Langan, A.A. Maurer, Recent Philosophy Hegel to the Present, New York 1966, s. 595.

${ }^{12}$ B.P. Bowne, Theism, dz. cyt., s. 86.

${ }^{13}$ Tamże, s. 122.

${ }^{14}$ Tamże, s. 127.

15 Tamże, s. 141

${ }^{16}$ W.E. Steinkraus, A Century of Bowne's Theism, w: Personalism revisited. Its Proponents and Critics, ed. T.O. Buford, H.H. Oliver, Amsterdam [New York] 2002, s. 10-11.

${ }^{17}$ P.A. Bertocci, Borden Parker Bowne..., dz. cyt., s. 72.

${ }^{18}$ B.P. Bowne, Personalizm, Lublin 1994, s. 77; por. B. Gacka, Personalizm amerykański, Lublin 1996, s. 41. 
Bowne był świadomy, że znaki istniejące w naturze nie są w stanie w pełni dowieść istnienia Boga, a szczególnie Jego konkretnych atrybutów. Celowość w naturze nie jest bezwzględnie oczywista. Mimo tego Bowne nigdy nie podważał dobroci i wszechmocy Boga, wskazując raczej na ograniczenia ludzkiego poznania $^{19}$.

W argumentacji na rzecz teizmu filozof amerykański wspomina również o doświadczeniu religijnym. Ma ono pewną wartość dla uzasadniania teizmu. Nie może ono być jednakże w tym kontekście argumentem przesądzającym, choć pozostaje dla niego argumentem wspomagającym.

\section{NATURA JAKO WYRAZ MYŚLI ORAZ WOLI OSOBY NAJWYŻSZEJ}

Bowne przeciwstawia się materialistycznemu pojmowaniu natury, natomiast opowiada się za jej rozumieniem personalistycznym. Natura jest według niego efektem działania Stwórcy, a nie przyczyną samą w sobie, ponieważ nie zawiera w sobie ani faktycznego przyczynowania, ani jakiejkolwiek konieczności ${ }^{20}$. Jest za to niesubstancjalnym wyrazem ukrywającego się za nią Ducha ${ }^{21}$. W całym swym personalizmie, jak również w przypadku analizy problemu natury, filozof amerykański odnosi się konsekwentnie do Osoby Najwyższej.

Bowne odchodzi od rozumienia natury jako samoistnej substancji (przyrody), ale także pośrednio od klasycznego rozumienia natury (Arystoteles) jako zasady działania. Istnieje dla niego tylko jedna natura, a jest nią działanie Boga. Czym są w takim ujęciu działania bytów materialnych? Po pierwsze, byty materialne nie są bytami sensu stricte, a po drugie, prawa, którymi się kierują, są po prostu ujawnianiem się Bożego działania.

Natura nie jest substancjalna, ponieważ jest działaniem Najwyższej Osoby i właściwie tylko On jest substancją. Osobom skończonym porządek przyczynowy dostępny jest za to jako zjawisko. Na przykład doświadczenie zmiany jest osobową reakcją człowieka na działanie Stwórcy. Idąc dalej, natura nie jest porządkiem następstwa, bo w takim wypadku nie moglibyśmy się w niej doszukiwać inteligibilności. Ważne, aby zaznaczyć, że rozumne i wolne działanie Boga nie stwarza tylko postrzeżeń dla osób skończonych, lecz cały obiektywny świat doświadczenia. Natura jest zatem działaniem Stwórcy w wymiarze kosmicznym. Rzeczywistość to Boża myśl, która wyraża się w Jego działaniu. Można powiedzieć, że Najwyższa Osoba pozostaje immanentna w naturze, ale z drugiej strony się w niej nie wyczerpuje, a świat zjawiskowy powstaje wtedy,

${ }^{19}$ P.A. Bertocci, Borden Parker Bowne..., dz. cyt., s. 74.

${ }^{20}$ B.P. Bowne, Metaphysics, dz. cyt., s. 262.

${ }^{21}$ F. Ferré, Personalism and the Dignity of Nature, w: Personalism revisited. Its Proponents and Critics, dz. cyt., s. 110. 
gdy działanie Najwyższej Osoby spotyka się z aktywnością poznawczą osób skończonych ${ }^{22}$. Tout court, natura to dla Bowne'a funkcja woli i celu Najwyższej Osoby, która funduje jedność zjawisk przyrodniczych ${ }^{23}$, bo zakładając, że znajdujemy się w świecie osobowym, także przyczyn istnienia przyrody trzeba szukać w świecie osób ${ }^{24}$.

Bowne nie chce rezygnować z celowości świata na rzecz porządku praw przyrody - tj. redukcjonistycznego naturalizmu. Przeciwstawienie celowości i przyczynowości jest według niego nieuzasadnione ${ }^{25}$. Usprawiedliwione jest za to określanie natury jako zasady, która determinuje formę oraz charakter działania rzeczy w taki sposób, w jaki dają się one poznać osobom skończonym.

Natura jest zatem forma, dzięki której ujawnia się Najwyższy Rozum oraz Wola $^{26}$, czyli formą oraz efektem nieustannej aktywności Boga ${ }^{27}$. Nature is speech, not existence ${ }^{28}$ - powiada filozof. Mamy tu zatem połączenie rozumienia natury jako przyrody oraz natury jako zasady działania, gdzie obie są odniesione do Osoby Najwyższej.

Natura nie jest, zdaniem Bowne'a, zamkniętym systemem, z którego moglibyśmy wyprowadzić dedukcyjnie poszczególne zdarzenia. Byłby to rzeczywiście cud, gdyby u podstaw tego systemu nie leżała osobowa celowość Stwórcy, a mimo to tworzyłby znany nam ład kosmiczny. W takim systemie wolność i rozumność człowieka nie są zagrożeniem, a raczej wyrazem celowości Działającego, który poprzez znany człowiekowi świat wyraża swój zamysł ${ }^{29}$.

\section{BÓG JAKO OSOBA}

Bowne nie chciał przyjąć wizji Boga pozbawionego takich cech moralnych jak dobroć, miłość czy troska o świat stworzony ${ }^{30}$. Bóg ukazuje się zarówno jako spełnienie estetycznej, moralnej i religijnej natury człowieka, jak i jego emocjonalnych potrzeb. W tym kontekście wiara w Boga opiera się także na mocy odczuwania ${ }^{31}$.

${ }^{22}$ P.A. Bertocci, Borden Parker Bowne and His Personalistic Theistic Idealism, w: The Boston Personalist Tradition in Philosophy, Social Ethics, and Theology, dz. cyt., s. 213.

${ }^{23}$ B. Gacka, Personalizm amerykański, Lublin 1996, s. 49.

${ }^{24}$ Por. R. Burrow, Personalism a critical introduction, St. Louis [Missouri] 1999, s. 32.

${ }^{25}$ B.P. Bowne, The Immanence of God, Boston 1905, s. 14-15.

26 "Nature is simply the form under which the Supreme Reason and Will reveal themselves" tamże, s. 17.

${ }^{27}$ Tamże, s. 24.

${ }^{28}$ B.P. Bowne, Theism, dz. cyt., s. 134.

${ }^{29}$ P.A. Bertocci, Borden Parker Bowne..., dz. cyt., s. 65.

${ }^{30}$ B.P. Bowne, Personalism, Boston-New York 1906, s. 296-297.

${ }^{31}$ B.P. Bowne, The Logic of Religious Belief, w: Representative Essays of Borden Parker Bowne, ed. W.E. Steinkraus, New York 1981, s. 154. 
Bóg jest dla Bowne'a ostatecznym odniesieniem w rozumieniu człowieka jako osoby. Intelekt posiada rodzaj doskonałości, do której zmierza, podobnie zachowuje się świadomość oraz uczucia. Gdy zbierzemy razem te docelowe doskonałości oraz podniesiemy do stanu pełnego spełnienia, wskażą nam one Doskonały Byt, doskonałość doskonałości - najwyższy i kompletny ${ }^{32}$.

Bowne był zdania, że na temat Boga nie może wypowiadać się wiarygodnie ktoś, kto nie był nigdy w żadnej świątyni i nigdy się nie modlił. Ktoś taki nie jest w stanie zrozumieć doświadczenia religijnego innych osób. Teizmu nie można stąd traktować jako problemu zaledwie abstrakcyjnego, ponieważ w swej istocie jest on nierozerwalnie związany z praktycznym życiem i najgłębszymi potrzebami człowieka ${ }^{33}$.

Uważał ponadto, że zarówno teizm, jak i ateizm nie są oczywistymi prawdami i oba domagają się uzasadnienia. Nie jest tak, że za ateizmem przemawiają fakty, a teizm trzeba udowadniać teoretycznie. W obu przypadkach mamy do czynienia z teoriami, które musi osądzić sam rozum ${ }^{34}$.

Aby uniknąć abstrakcyjnego mówienia o Bogu, Bowne nie chciał zgodzić się na koncepcję creatio ex nihilo, ponieważ Bóg odpowiada zawsze poprzez naturę skończonym osobom, nie ingerując przy tym arbitralnie w ich wolność, choć same skończone osoby zależą bezwzględnie od Niego w realizacji swojej stworzonej tożsamości. Czy Bóg mógłby istnieć bez świata? Dla Bowne’a Bóg jest Tym, w którym żyjemy, poruszamy się i jesteśmy; który jest na tyle bliski, aby można było Go kochać, i na tyle daleki, aby można było Go adorować3 ${ }^{35}$.

\section{ATRYBUTY BOGA JAKO OSOBY}

Jak wspomnieliśmy wyżej, Bóg jako Najwyższa Osoba stanowi dla filozofa amerykańskiego wzór życia osobowego. Cechy, jakimi charakteryzuje się ten Najwyższy Byt Osobowy, będzie on stosował także do osób skończonych. Bóg staje się w ten sposób wzorem wszelkiej rzeczywistości osobowej. Zobaczmy zatem, jakie cechy Najwyższej Osoby opisuje Bowne.

Bóg jest najpierw jednością w sobie, jest niezłożony z części, niepodzielny, mający tylko jeden akt istnienia ${ }^{36}$. Jako Osobowa Podstawa świata Bóg zabezpiecza jedność doświadczenia wszystkich osób skończonych, cechuje Go ponad-

\footnotetext{
32 "The intellect brings its ideals; the conscience brings its ideal; and the affections bring their ideals; and these together with whatever other thought of perfection we may have, are united into one Perfect Being, the ideal of ideals, the supreme and complete" - B.P. Bowne, Philosophy of Theism, New York 1887, s. 21.

${ }^{33}$ W.E. Steinkraus, A Century of Bowne's Theism, dz. cyt., s. 6-7.

${ }^{34}$ Tamże, s. 13.

${ }^{35}$ P.A. Bertocci, Borden Parker Bowne..., dz. cyt., s. 77.

${ }^{36}$ B.P. Bowne, Theism, dz. cyt., s. 173, 177.
} 
to działanie moralne oraz $\mathrm{w}$ pełni odpowiedzialne ${ }^{37}$. Jedność osobowego Boga zakłada Jego wolność w relacji do stworzenia, uzasadniając zarazem zaufanie do władz umysłowych człowieka ${ }^{38}$.

Następną cechą Boga jest niezmienność. Bóg jako wolna Osoba może inicjować zmianę, choć sam jej nie podlega. Niezmienność Boga nie znaczy bycia poza zmiana, lecz raczej doskonałe samoposiadanie oraz samorealizację, a stąd też doskonałą wolność ${ }^{39}$. „Niezmienność Boga oznacza tylko stałość i ciagłość Boskiej natury, która istnieje poprzez wszelkie Boże działania jako ich prawo i źródło" [tłum. A. J. $]^{40}$.

Poszukując czegoś tak stałego dochodzimy do pojęcia osoby. Nie chodzi tu nawet o jakieś niezmienne centrum bytowe, lecz o spajającą moc samoświadomości. Niezmienność jest ufundowana na niezmiennej jaźni. Zasadę tę Bowne stosuje także do osób skończonych - także tożsamość człowieka powstaje dzięki niezmienności jego jaźni.

Bóg jest też wieczny, natomiast człowiek podlega ograniczeniom czasu. Relacja Boga do czasu nie jest taka sama jak czasowość człowieka, który rodzi się, rozwija i umiera. W tym sensie Bóg musi być pozaczasowy, ponieważ doskonale siebie posiada i nie potrzebuje rozwoju. Bóg jest nie tylko wieczny, ale właściwie pozaczasowy, choć Jego działanie postrzegamy w czasie ${ }^{41}$. Spojrzenie człowieka na czas pozostaje z konieczności względne. Nie wynika to wprost ze sposobu pracy samego intelektu, lecz raczej z charakteru jego wytworów. Umysł Boga musi znajdować się poza ograniczeniami czasu - jest bowiem ich źródłem, ale się w nich nie zawiera ${ }^{42}$.

Kolejna cecha Bytu Najwyższego to wszechobecność. Nie znaczy to, że świat istnieje w Bogu ani poza Nim. Zdaniem Bowne'a, faktu wszechobecności nie powinniśmy rozumieć $\mathrm{w}$ sensie przestrzennym. Nie ulega wątpliwości, że świat jest zależny od Boga, ale nie należy sobie tego wyobrażać fizycznie. Ta zależność dotyczy raczej umysłu Boga, który jest obecny w świecie tak, jak umysł w swych myślach, i to nie jako jakaś aura czy nawet przedmiot, lecz jako aktywny podmiot, od którego cała rzeczywistość zależy w istnieniu ${ }^{43}$. Również w przypadku osób skończonych Bowne mówi o aktywnym podmiocie obecnym w swych myślach. Obecność ta jest jednak bardziej ograniczona niż obecność Boga. Przyjmując przestrzeń jako kategorię ludzkiego intelektu, możemy łatwiej uzasadnić wszechobecność samego Boga ${ }^{44}$.

\footnotetext{
${ }^{37}$ F.J. McConnell, Borden Parker Bowne, New York-Cincinnati-Chicago 1929, s. 148.

${ }^{38}$ P.A. Bertocci, Borden Parker Bowne and His Personalistic Idealism, dz. cyt., s. 221.

${ }^{39}$ A.C. Knudson, The Philosophy of Personalism, New York-Cincinnati-Chicago 1927, s. 236.

${ }^{40}$ B.P. Bowne, Theism, dz. cyt., s. 178.

${ }^{41}$ Tamże, s. 185.

${ }^{42}$ Tamże, s. 186.

${ }^{43}$ B.P. Bowne, Metaphysics, dz. cyt., s. 119.

${ }^{44}$ B.P. Bowne, Theism, dz. cyt., s. 180-181.
} 
Najwyższa Osoba ma także wszechwiedzę. Jest to wiedza o rzeczach przeszłych, obecnych i przyszłych - wiedza konieczna i wolna ${ }^{45}$. Bóg ma absolutną wiedzę także o sobie oraz pełną samokontrolę ${ }^{46}$. Człowiek nie dysponuje wiedzą absolutną jednakże ważną cechą bytu ludzkiego jest zdolność samokontroli.

Bóg jest wszechmocny. Tylko świadomy intelekt jest w stanie sobą kierować, a w sposób najdoskonalszy czyni to Intelekt Najwyższy ${ }^{47}$. Człowiek został również obdarzony świadomą inteligencją oraz zdolnością samokierowania.

Bóg jest dobry. Najwyższe objawienie dobroci Boga znajdujemy w szlachetnych osobach, choć nie znaczy to, że one same bezwzględnie odbijają dobroć $\operatorname{Boga}^{48}$. Jest rzeczą rozsądną przyjać, że skoro skończone umysły dążą do dobra, wartość ta musi istnieć tym bardziej w ostatecznej Przyczynie Świata ${ }^{49}$.

Bóg jest zaangażowany w stworzenie, działając na jego rzecz z miłością oraz współczuciem. Każda osoba ludzka ma nieskończoną godność wobec Boga. Z tej też przyczyny Bóg zobowiązuje się do troski o każdą z nich ${ }^{50}$. Miłość jest właściwym zwieńczeniem teizmu Bowne'a. Bóg jest transcendentny wobec świata, ponieważ wszystko od Niego zależy w istnieniu, ale także immanentny, gdyż podtrzymuje świat w jego bycie. Miłość Boga ma korzenie głęboko w samym życiu, a będąc źródłem stworzenia, jest istotą Bożej Natury ${ }^{51}$. Bóg pozostaje też w trwałej relacji do świata: jest jego Stworzycielem oraz zachowuje go $\mathrm{w}$ istnieniu ${ }^{52}$.

Bóg jest dla Bowne'a wszechobecną podstawą wszelkiego istnienia, wiecznym, zawsze obecnym i działającym Panem ${ }^{53}$. O panowaniu Boga możemy mówić tylko wtedy, gdy istnieją byty, które na mocy własnej decyzji mogą wyłączyć się spod tego panowania. Taką zdolność mają tylko skończone osoby. Tylko one mogą korzystać z takiej wolności, która nie jest celem, lecz środkiem do celu.

Podsumowując, warto przypomnieć, że wedle Bowne'a osobą par exellence jest Osoba Najwyższa (Bóg), która ma wszystkie cechy osobowe w stopniu najwyższym - jest to Byt Nieskończony i Absolutny ${ }^{54}$. Poznanie Najwyższej Osoby jest trudne, ale nie mniej skomplikowanym zadaniem jest także poznanie człowieka jako osoby ${ }^{55}$, którego istnienie jest dane przecież jako rzeczywisty fakt $t^{56}$.

${ }^{45}$ Tamże, s. 186-187.

${ }^{46}$ Tamże, s. 187.

${ }^{47}$ H.E. Langan, The Philosophy of Personalism and Its Educational Applications, Washington, D. C. 1935 , s. 18.

${ }^{48}$ R. Burrow, Personalism a critical introduction, dz. cyt., s. 149.

${ }^{49}$ E. Gilson, T. Langan, A.A. Maurer, Recent Philosophy..., dz. cyt., s. 595.

${ }^{50}$ R. Burrow, Personalism a critical introduction, dz. cyt., s. 150.

${ }^{51}$ B.P. Bowne, Theism, dz. cyt., s. 256.

${ }^{52}$ Tamże, s. 230.

${ }^{53}$ B.P. Bowne, The Immanence of God, dz. cyt., s. 3.

54 " [...] complete and perfect personality can be found only in the Infinite and Absolute Being [...]". B.P. Bowne, Personalism, dz. cyt., s. 266.

${ }^{55}$ B. Gacka, Personalizm amerykański, dz. cyt., s. 31.

${ }^{56}$ B.P. Bowne, Personalizm, dz. cyt., s. 165. 
Osoba ludzka nie posiada w sobie przyczyny własnego istnienia. Bowne nie rozumie Osoby Boga wyłącznie antropomorficznie ani nie twierdzi, że klucz do rzeczywistości znajdziemy w jakieś konkretnej osobie ludzkiej. Im bardziej redukujemy cechy specyficznie ludzkie w opisie osoby, tym bardziej zbliżamy się do źródła, o którym powiedziano, że jesteśmy stworzeni „na Jego obraz”. W tym sensie możemy powiedzieć, że osoba ludzka jest teomorficzna, tj. stworzona na obraz i podobieństwo Boże. Jeśli jednak osoba ludzka odbija w sobie Osobę Najwyższą, to może także w sobie samej poszukiwać odpowiedzi na niektóre pytania dotyczące rzeczywistości ostatecznych ${ }^{57}$.

Absolutną wiedzę oraz samokontrolę (wolność), które byłyby znakiem doskonałej osoby, odnajdujemy wedle filozofa amerykańskiego tylko w Bogu jako najdoskonalszej Osobie. Od Niego to właśnie wszystko zależy w istnieniu, w Nim jest czyste samookreślenie oraz doskonałe posiadanie siebie. Osoba ludzka jest ostatecznie tylko odbiciem Tego, który sam jest Osobą doskonałą ${ }^{58}$.

\section{OSOBA LUDZKA A OSOBA BOGA}

Jeśli idzie o Osobę Boga, to pozostaje Ona według Bowne’a zawsze okryta jakąś tajemnicą - i to dużo większą niż osoba ludzka. Kształtowanie rozumienia osoby ludzkiej na podstawie Osoby Najwyższej jest jednym z ważnych punktów opisu bytu ludzkiego charakterystycznym dla filozofa amerykańskiego.

Bóg jest najlepszym wyjaśnieniem tego, co to znaczy być osobą, i właściwie tylko Osoba Boska jest doskonale osobą przez to, że posiada w najwyższym stopniu świadomość, samoświadomość, wiedzę i samopanowanie ${ }^{59}$. „Tylko w Nim bowiem możemy odnaleźć tę pełną i doskonałą podmiotowość oraz samoposiadanie, które są konieczne, aby można było mówić o pełni osobowości. W myśleniu zatem o Najwyższej Osobie musimy unikać przenoszenia na tę Osobę ograniczeń i przypadłości wynikających z naszej ludzkiej osobowości”60.

Uwypuklając zależność osoby skończonej w sposób abstrakcyjny i absolutny, możemy łatwo popaść w panteizm - kontynuuje Bowne ${ }^{61}$. Zabezpieczeniem przed takim błędem jest uznanie wolności tak skończonego, jak i nieskończonego ducha

Że Bóg zna nasze myśli i uczucia oraz rozumie je doskonale i akceptuje, to zupełnie zrozumiałe. Jednak pogląd, że nasze myśli i uczucia są jego myślami i uczuciami w jakimś sensie, to już sprzeczność logiczna. Gdybyśmy jednak mimo to upierali się

\footnotetext{
${ }^{57}$ R. Burrow, Personalism a critical introduction, dz. cyt., s. 96-97.

${ }^{58}$ B.P. Bowne, Theism, dz. cyt., s. 168.

${ }^{59}$ R. Burrow, Personalism a critical introduction, dz. cyt., s. 102-103.

${ }^{60}$ B.P. Bowne, Personalizm, dz. cyt., s. 166.

${ }^{61}$ Tamże, s. 175.
} 
przy takim twierdzeniu, wtedy rozum popełniłby po prostu samobójstwo. Jeśli to Bóg myśli i czuje w naszym myśleniu i odczuwaniu, wobec tego Bóg także błądzi w naszym błądzeniu i jest głupi w naszej głupocie; to także Bóg sam sobie przeczy W oceanie sprzeczności naszego myślenia. W ten sposób błąd, kaprys i grzech stają się boskie, znika zaś autorytet rozumu i sumienia ${ }^{62}$.

Opis relacji nieskończonej Podstawy Świata do skończonych osób oraz do porządku zjawisk Bowne odnosi do skończoności albo nieskończoności. Jest to odpowiednio zależność przyczynowa i zależność finalna (celowa). Nieskończoność filozof amerykański rozumie jako jednoczące i niepodzielne działanie Najwyższej Osoby. Skończoność nie jest zaś częścią Nieskończoności tak, jakoby Nieskończoność mogłaby być fizycznie podzielna lub modyfikowalna. Świat zjawisk jest działaniem energii Nieskończonego, a wolne osoby są owocem Jego działalności stwórczej i tylko one mogą pozostawać w prawdziwej relacji stworzenie - Stworzyciel ${ }^{63}$.

Istnienie człowieka pochodzi od Osoby Najwyższej i zależy od Jej woli i celu. Osoba skończona istnieje w relacji do Osoby Boskiej, która jednocześnie stanowi ograniczenie tego istnienia ${ }^{64}$. Osoba skończona ma świadomość zależności od Kogoś poza nią samą. Wewnątrz siebie odkrywamy różne ograniczenia. Nie potrafimy też odtworzyć dokładnie przeszłości, a teraźniejszość nie poddaje się całkowicie naszemu działaniu. Bylibyśmy absolutnymi osobami, gdybyśmy mogli całkowicie wpływać na nasze istnienie. Tak jednak nie jest i jesteśmy świadomi naszych ograniczeń oraz tego, że nie istniejemy dzięki sobie, lecz dzięki Innemu, od którego pochodzi nasz sposób istnienia oraz działania ${ }^{65}$.

\section{OSOBOWY BÓG JAKO FUNDAMENT PERSONALIZMU}

Bowne twierdzi, że cały system rzeczy materialnych nie ma istnienia w sobie, lecz w bycie Nieskończonym, który sam pozostaje Fundamentem istnienia. Każdy byt skończony: materialny czy duchowy, zawdzięcza swe istnienie Stworzycielowi. Jeśli plan Stwórcy nie zawierałby już tego istnienia, byt taki przestałby istniećc6.

Filozof amerykański nie używa zbyt często słowa Stworzyciel, aby uniknąć skojarzeń antropomorficznych. Określa Boga w tym aspekcie raczej jako Pod-

${ }^{62}$ Tamże, s. 176.

${ }^{63}$ G.W. Cunningham, The Idealistic Argument in Recent British and American Philosophy, Freeport [New York] 1933 (1967 - reprinted), s. 330-331.

${ }^{64}$ B.P. Bowne, Theism, dz. cyt., s. 163-164.

${ }^{65}$ Tamże, s. 167-168.

${ }^{66}$ B.P. Bowne, The Significance of The Body for Mental Action, w: Representative Essays of Borden Parker Bowne, dz. cyt., s. 23. 
stawę Świata (World Ground). Takie ujęcie może prowadzić jednak do postawy apersonalnej, dlatego dodaje zwykle przymiotnik „osobowa”. „Osobowa Podstawa Świata" - to ostateczne sformułowanie Bowne'a.

Dla Boga być, znaczy działać. To działanie dokonuje się poprzez naturę. Określenie bytu jako działającego ma kluczowe znaczenie dla całego personalizmu Bowne’a, ponieważ również człowiekowi przypisuje status bytu właśnie dzięki aktywności. „Być znaczy działać” także w przypadku człowieka.

Cały wysiłek filozoficzny Bowne'a osiagga swe wypełnienie w porządku duchowym. Stworzenie może dokonać się w czasie lub poza nim ze względu na wolność Boga. Świat rzeczy swe uzasadnienie znajduje w wolnych osobach, one zaś w Bogu. Istnieją jedynie osoby skończone, którym dostępne jest poznanie fragmentaryczne, oraz Osoba mająca pełnię doświadczenia, od której osoby skończone bytowo zależą ${ }^{67}$.

Teizm dla filozofa amerykańskiego jest racjonalną koniecznością, do której dochodzi w wyniku swych poszukiwań filozoficznych. Świat to zespół bytów duchowych. Teista uznaje Boga, który jest zawsze obecny w świecie i podtrzymuje go w istnieniu; Boga, który jest ostateczną przyczyną tego, co istnieje, i który ustanawia prawa, dzięki którym świat jawi się jako inteligibilny ${ }^{68}$. Taki jest fundament teizmu Bowne'a.

\section{ZAKOŃCZENIE}

Teistyczny personalizm Bowne'a prawdopodobnie nie był absolutną nowością, ale jego uzasadnienie było jednak na tyle oryginalne, że stał się jego głównym propagatorem w USA. Podobne teorie wysuwali już inni jemu współcześni jak Georges H. Howison, George T. Ladd, George S. Morris i Geoffrey H. Palmer w Stanach Zjednoczonych oraz Hustings Rashdall, William R. Sorley, George F. Stout, H. Sturt i James Ward w Wielkiej Brytanii. Bowne wskazał jednak bardzo wyraźnie na centralną rolę działającej osoby. W swym personalizmie dawał wyróżnione miejsce Bogu - Najwyższej Osobie, stając się prawdopodobnie najbardziej zagorzałym teistą amerykańskim ${ }^{69}$.

Obrońca praw człowieka oraz laureat Pokojowej Nagrody Nobla Martin Luter King Jr. stwierdził, że personalizm Bowne’a był dla niego filozoficznym oparciem oraz metafizyczną podstawą dla promowania godności osoby ludzkiej ${ }^{70}$. Zaangażowanie na rzecz praw człowieka jest wyznacznikiem trendu, jaki obrali spadkobiercy Bowne’a w czasach współczesnych, przekształcając personalizm

\footnotetext{
${ }^{67}$ L. Farré, Personalistic Idealism of Bowne, dz. cyt., s. 55.

${ }^{68}$ B.P. Bowne, The Immanence of God, dz. cyt., s. 24-25.

${ }^{69}$ J.W. Buckham, Borden Parker Bowne: Personalist, "The Personalist" V (1924), s. 96.

${ }^{70}$ W.E. Steinkraus, Preface, w: Representative Essays of Borden Parker Bowne, dz. cyt., s. II.
} 
bardziej w filozofię praktyczną, a nawet ruch społeczny daleki od spekulacji czysto teoretycznych ${ }^{71}$.

Rola Bowne'a w historii filozofii nie jest chyba dostatecznie doceniana, choć jego wpływ na kulturę filozoficzną w USA nie był bez znaczenia. Pomimo to Bowne rzadko bywa cytowany w debatach filozoficznych. Przyczyną tego jest najprawdopodobniej niewypowiadane założenie, że był uznawany przez środowisko filozofów raczej za teologa niż za filozofa. Założenie to może znaleźć swe uzasadnienie $\mathrm{w}$ żywym zainteresowaniu filozofa amerykańskiego problemami religijnymi, które nieraz wpływają na prezentowane przez niego rozwiązania filozoficzne.

Pomimo tych ograniczeń, które do pewnego stopnia możemy przypisać personalizmowi Bowne'a, trzeba przyznać, iż filozof amerykański odniósł się w nim do większości ważnych zagadnień filozoficznych i w efekcie przedstawił całościowe spojrzenie na filozofię, które jest warte odnotowania ${ }^{72}$. Bez wątpienia filozofowie Bowne'owi współcześni jak: Josiah Royce, Charles S. Peirce oraz William James pozostają bardziej znani. Teistyczny personalizm Bowne'a pozostaje jednak najbardziej rozciągłym w czasie i jednocześnie najbardziej rozwiniętym kierunkiem filozoficznym w Ameryce ${ }^{73}$.

Nie ma wątpliwości, że myśl Bowne'a stanowiła poważny wkład w amerykańską edukację teologiczną. Świadczy o tym choćby to, że większość duchownych, a nawet biskupów metodystycznych przyjmowała istotne punkty personalizmu Bowne'a, broniącego teizm w czasach, kiedy w świecie filozoficznym tracił on stopniowo zainteresowanie ${ }^{74}$.

Kontynuatorem teizmu Bowne'a był jeden z jego najbardziej znanych uczniów Edgar S. Brightman, który na polu etyki rozwinął metodę empirycznej koherencji dla uzasadnienia systemu moralnego. Jednak przede wszystkim był on twórcą wersji „skończonego" teizmu. Proponował w nim przyjęcie założenia, że doskonała wola Boga jest ograniczona poprzez granice Jego własnej natury. Chodziło o to, że wola Boga nie chybi co prawda w swym działaniu, jednak musi brać pod uwagę pewne ograniczenia tego, co dane. Zmaganie się Boga z ograniczeniami natury jest procesem dynamicznym, który dąży ostatecznie do coraz większej doskonałości tak samego Boga, jak i stworzonego Przezeń świata ${ }^{75}$. Zagadnienia wysuwane przez Brightmana mogłyby stać się przedmiotem osobnego, pogłębionego studium.

\footnotetext{
${ }^{71}$ Por. A. Jastrzębski, Pierwszy personalista amerykański. Personalizm Bordena Parkera Bow$n e^{\prime} a$, Lublin 2008, s. 163-164.

${ }^{72}$ G.W. Cunningham, The Idealistic Argument, dz. cyt., s. 315.

${ }^{73}$ P. Deats, Introduction to Boston Personalism, w: The Boston Personalist Tradition in Philosophy, Social Ethics, and Theology, dz. cyt., s. 3.

${ }^{74}$ H.H. Oliver, Klasyczny personalizm bostoński, "Personalizm" 9(2005), s. 61-63.

${ }^{75}$ E.S. Brightman, Is God a Person?, New York 1932; por. też: L.H. DeWolf, Personalism in the History of Western Philosophy, "The Philosophical Forum” 12(1954), s. 50.
} 


\section{BIBLIOGRAFIA}

Bertocci P.A., Borden Parker Bowne and His Personalistic Theistic Idealism, w: The Boston Personalist Tradition in Philosophy, Social Ethics, and Theology, ed. P. Deats, C. Robb, Mercer University Press Macon, Macon [Georgia] 1986, s. 55-80.

Bowne B.P., Personalizm, tłum. J. Kłos, B. Gacka, Oficyna Wydawnicza „Czas”, Lublin 1994.

Bowne B.P., Theism, American Book Company, New York 1902.

Bowne B.P., Philosophical Idealism, w: Representative Essays of Borden Parker Bowne, ed. W.E. Steinkraus, Meridian Publishing Co.New York 1981, s. 3-15.

Bowne B.P., Metaphysics: A Study in First Principles, Harper \& Brothers, New York 1898.

Bowne B.P., The Immanence of God, Houghton Mifflin, Boston 1905.

Bowne B.P., Personalism, Mifflin and Company, Boston-New York 1906.

Bowne B.P., The Logic of Religious Belief, w: Representative Essays of Borden Parker Bowne, ed. W.E. Steinkraus, Meridian Publishing Co., New York 1981, s. 149-165.

Bowne B.P., The Significance of The Body for Mental Action, w: Representative Essays of Borden Parker Bowne, ed. W.E. Steinkraus, Meridian Publishing Co., New York 1981, s. 16-23.

Bowne B.P., Philosophy of Theism, Harper \& Brothers, New York 1887.

Brightman E.S., Is God a Person?, Association Press, New York 1932.

Buckham J.W., Borden Parker Bowne: Personalist, „The Personalist” 5(1924), s. 88-100.

Burrow R., Personalism a critical introduction, Chalice Press, St. Louis [Missouri] 1999.

Cunningham G.W., The Idealistic Argument in Recent British and American Philosophy, Century, Freeport [New York] 1933 (1967 - reprinted).

Deats P., Introduction to Boston Personalism, w: The Boston Personalist Tradition in Philosophy, Social Ethics, and Theology, ed. P. Deats, C. Robb, Mercer Press, Macon [Georgia] 1986, s. 1-13.

DeWolf L.H., Personalism in the History of Western Philosophy, "The Philosophical Forum" 12(1954), s. 29-51.

Farré L., Personalistic Idealism of Bowne, „The Personalist” 30(1949), s. 51-56.

Ferré F., Personalism and the Dignity of Nature, w: Personalism revisited. Its Proponents and Critics, ed. T.O. Buford, H.H. Oliver, Rodopi, Amsterdam [New York] 2002, s. 105-122.

Gacka B., Personalizm amerykański, KUL, Lublin 1996.

Gilson E., Langan T., Maurer A.A., Recent Philosophy Hegel to the Present, Random House, New York 1966.

Jastrzębski A., Zarys personalistycznej metafizyki Bordena Parkera Bowne’a, ,Roczniki Filozoficzne KUL” 1(2008), s. 397-415. 
Jastrzębski A., Pierwszy personalista amerykański. Personalizm Bordena Parkera Bowne'a, KUL, Lublin 2008.

Jastrzębski A., Problem mind - body w ujęciu Szkoły Bostońskiej na przykładzie Bordena Parkera Bowne'a, „Kwartalnik Filozoficzny” 2(2010), s. 83-105.

Knudson A.C., The Philosophy of Personalism, The Abingdon Press, New York-Cincinnati-Chicago 1927.

Langan H.E., The Philosophy of Personalism and Its Educational Applications, The Catholic University of America Washington, D. C. 1935.

McConnell F.J., Borden Parker Bowne, The Abingdon Press, New York-Cincinnati-Chicago 1929.

Oliver H.H., Klasyczny personalizm bostoński, „Personalizm” 9(2005), s. 61-70.

Schneider H.W., Bowne's Radical Empiricism, w: Representative Essays of Borden Parker Bowne, ed. W.E. Steinkraus, Meridian Publishing Co., New York 1981, s. xi-xv.

Steinkraus W.E., A Century of Bowne's Theism, w: Personalism revisited. Its Proponents and Critics, ed. T.O. Buford, H.H. Oliver, Rodopi, Amsterdam [New York] 2002, s. $5-21$.

Steinkraus W.E., Preface, w: Representative Essays of Borden Parker Bowne, ed. W.E. Steinkraus, Meridian Publishing Co., New York 1981, s. iii-ix.

\section{SUMMARY}

This presentation examines B. P. Bowne's view of God. God is an active and self-determining being. Nature is understood by Bowne as activated by the intellect and will of God. Bowne stated that each person has the attributes of awareness and self-awareness, freedom and the ability to act, and self-control - in a perfect way possessed only by God. Bowne's theistic personalism shows the human person to be a spiritual being, ultimately deriving from God, the Most-High Person.

\section{Keywords}

God, person, nature, theism

\section{Słowa kluczowe}

Bóg, osoba, natura, teizm 